\title{
Spatial and temporal distribution of the shrimp Nematopalaemon schmitti (Decapoda: Caridea: Palaemonidae) at a subtropical enclosed bay in South America
}

\author{
VIVIAN FRANSOZO ${ }^{1}$, ANTONIO LEÃO CASTILHO ${ }^{1}$, FÚLVIO AURÉLIO MORAIS FREIRE ${ }^{1,2}$, \\ MICHELE FURLAN ${ }^{1}$, ARIÁDINE CRISTINE DE ALMEIDA ${ }^{1}$, GUSTAVO MONTEIRO TEIXEIRA ${ }^{1}$ \\ AND JUAN ANTONIO BAEZA $3,4,5$
}

${ }^{1}$ NEBECC (Crustacean Biology, Ecology and Culture Study Group), Departamento de Zoologia, Instituto de Biociências, Universidade Estadual Paulista, 18.618.00o-Botucatu, SP, Brazil, ${ }^{2}$ Departamento de Ciências Animais, Universidade Federal Rural do Semi-Árido, 59625-900, Mossoró, RN, Brazil, ${ }^{3}$ Smithsonian Tropical Research Institute, Apartado Postal 0843-03092, Balboa, Ancón, Republic of Panama, ${ }^{4}$ Smithsonian Marine Station at Fort Pierce, 701 Seaway Drive, Fort Pierce, Florida 34949, USA, ${ }^{5}$ Departamento de Biología Marina, Facultad de Ciencias del Mar, Universidad Católica del Norte, Larrondo 1281, Coquimbo, Chile

\begin{abstract}
The spatio-temporal distribution of the soft bottom dwelling shrimp Nematopalaemon schmitti and the effect of environmental conditions (sediment characteristics, temperature, salinity and dissolved oxygen) on its abundance were studied at Ubatuba Bay, south-eastern coast of Brazil. Surveys were conducted monthly from September 1995 to August 1996. Each sampling set comprised eight different transects distributed within the bay. Comparisons of CPUE of shrimp among sampling stations demonstrated that the abundance of $\mathrm{N}$. schmitti was the greatest during winter, when average water temperature within the bay was considerably lower than during the rest of the year. Most shrimps (more than 95\%) were collected at a single transect located at the northernmost side of the bay, demonstrating the extremely patchy distribution of this species. A multiple regression analysis using data only from this northernmost transect indicated that temperature was the most relevant factor affecting the abundance of $\mathrm{N}$. schmitti during the year.
\end{abstract}

Keywords: distribution, abundance, temperature, shrimp, Ubatuba Bay, Brazil

Submitted 2 March 2009; accepted 5 May 2009; first published online 3 August 2009

\section{INTRDDUCTION}

Studies on the distribution, abundance, and population dynamics of marine organisms are most relevant given the pervasive effects of habitat degradation, alteration, and contamination on tropical and temperate areas around the world. Among crustaceans, most of these studies have been conducted in intertidal and shallow subtidal species from hard bottom environments (Jensen \& Armstrong, 1991; Nucci et al., 2001; Caillaux \& Stotz, 2003; Takeda et al., 2004; Pallas et al., 2006; Viegas et al., 2007). The distribution and conditions explaining the abundance of crustaceans from soft bottom habitats and environments deeper than $10 \mathrm{~m}$ are much less known.

The south-eastern Brazilian coast might be considered one out of a few localities in the southern hemisphere where intensive efforts to understand the distribution of soft bottom crustaceans have taken place. Most of the studies on this coast have focused on species of economic importance (Xiphopenaeus kroyeri (Heller, 1862)-Nakagaki \& Negreiros-Fransozo,

Corresponding author:

J.A. Baeza

Email: baezaa@si.edu
1998; Fransozo et al., 2002; Costa et al., 2007: Artemesia longinaris Bate, 1888-Fransozo et al., 2004; Costa et al., 2005a: Pleoticus muelleri (Bate, 1888) —Costa et al., 2004: Arenaeus cribrarius (Lamarck, 1818)-Pinheiro et al., 1994: Callinectes danae Smith, 1869-Chacur \& Negreiros-Fransozo, 2001). These studies suggest that the combined effect of temperature, sediment composition, and organic matter availability is most relevant in determining the distribution of crustaceans inhabiting soft bottom environments (Buchanan \& Stoner, 1988; Costa et al., 2005a, b; Fransozo et al., 2005; Henderson et al., 2006; Castilho et al., 2008a, b).

The white belly shrimp Nematopalaemon schmitti (Holthuis, 1950 ) is found from Venezuela to Brazil in marine and estuarine waters, from very shallow depths up to $75 \mathrm{~m}$ (Holthuis, 1980). This species is not commercially exploited given its small size, but it may play an important ecological role within the trophic web of soft bottom environments to which it pertains. Nematopalaemon schmitti is one of several by-catch species in fisheries targeting large penaeid shrimps, including Farfantepenaeus paulensis (Perez-Farfante, 1967), F. brasiliensis (Latreille, 1817), Litopenaeus schmitti (Burkenroad, 1936), and Xiphopenaeus kroyeri (Heller, 1862). Nevertheless, the biology of this shrimp is poorly known.

The aim of the present study was to characterize the temporal and spatial distribution of Nematopalaemon schmitti in 
a subtropical semi-enclosed bay located in the south-eastern Atlantic. We also attempted to identify those environmental conditions, namely, temperature, salinity, dissolved oxygen, and sediment characteristics, explaining the abundance of this shrimp at small temporal scales (within a year) at the study site.

\section{MATERIALS AND METHODS}

\section{Study site}

Ubatuba Bay $\left(23^{\circ} 25^{\prime} \mathrm{S}^{\prime} 45^{\circ} 03^{\prime} \mathrm{W}\right)$, located on the northern coast of São Paulo State, Brazil, faces eastward, and it is sheltered from southern and south-western waves coming from the open sea (Burone \& Pires-Vanin, 2006). This bay can be divided in a protected inner area (intertidal to $10 \mathrm{~m}$, low hydrodynamic energy) and an outer more exposed area $(10-16 \mathrm{~m})$. Within the bay, five sandy beaches are flanked by rocky shores (Figure 1). Freshwater from four small rivers (Indaiá, Grande, Lagoa and Acaraú) originating from the Atlantic coastal forest (Mata Atlântica) as well as smaller streams from surrounding mangrove-dominated areas flow into the bay. The effect of this freshwater discharge is the occasional decrease in salinity in the shallow areas of the bay.

\section{Shrimp collection and transect description}

To describe the spatio-temporal distribution of N. schmitti at Ubatuba Bay, shrimp samples were collected monthly from September 1995 to August 1996 using a fishing boat carrying two otter-trawl nets $(3.5 \mathrm{~m}$ wide; $15 \mathrm{~mm}$ and $10 \mathrm{~mm}$ mesh diameter at the body and cod end of the net, respectively). A total of 8 permanent transects were established within the outer (I, II, III and IV) and inner area (V, VI, VII and VIII) of the bay (Figure 1). During sampling, each transect was trawled for $1 \mathrm{~km}$ (each trawl lasted $\sim 30$ minutes). Each month, sampling was conducted during three consecutive days and covered a total area of $7 \mathrm{~km}^{2}$. Shrimps captured during each trawl were immediately stored in ethanol (70\%) and transported to the laboratory where they were counted.

During trawling, water samples taken with Nansen bottles were used for measuring dissolved oxygen, salinity and temperature at the different stations. For dissolved oxygen estimations, we employed the modified Winkler method that included the addition of azide (Golterman \& Clymo, 1969).

Sediment was collected at each transect with a $0.06 \mathrm{~m}^{2}$ Van Veen grab. Samples were transported to the laboratory and oven-dried $\left(70^{\circ} \mathrm{C}\right.$ for 72 hours). Grain size composition of the different samples was analysed following the protocols of Hakanson \& Jansson (1983) and Tucker (1988). In short, two sub-samples of $50 \mathrm{~g}$ were treated with $250 \mathrm{ml}$ of $\mathrm{NaOH}$
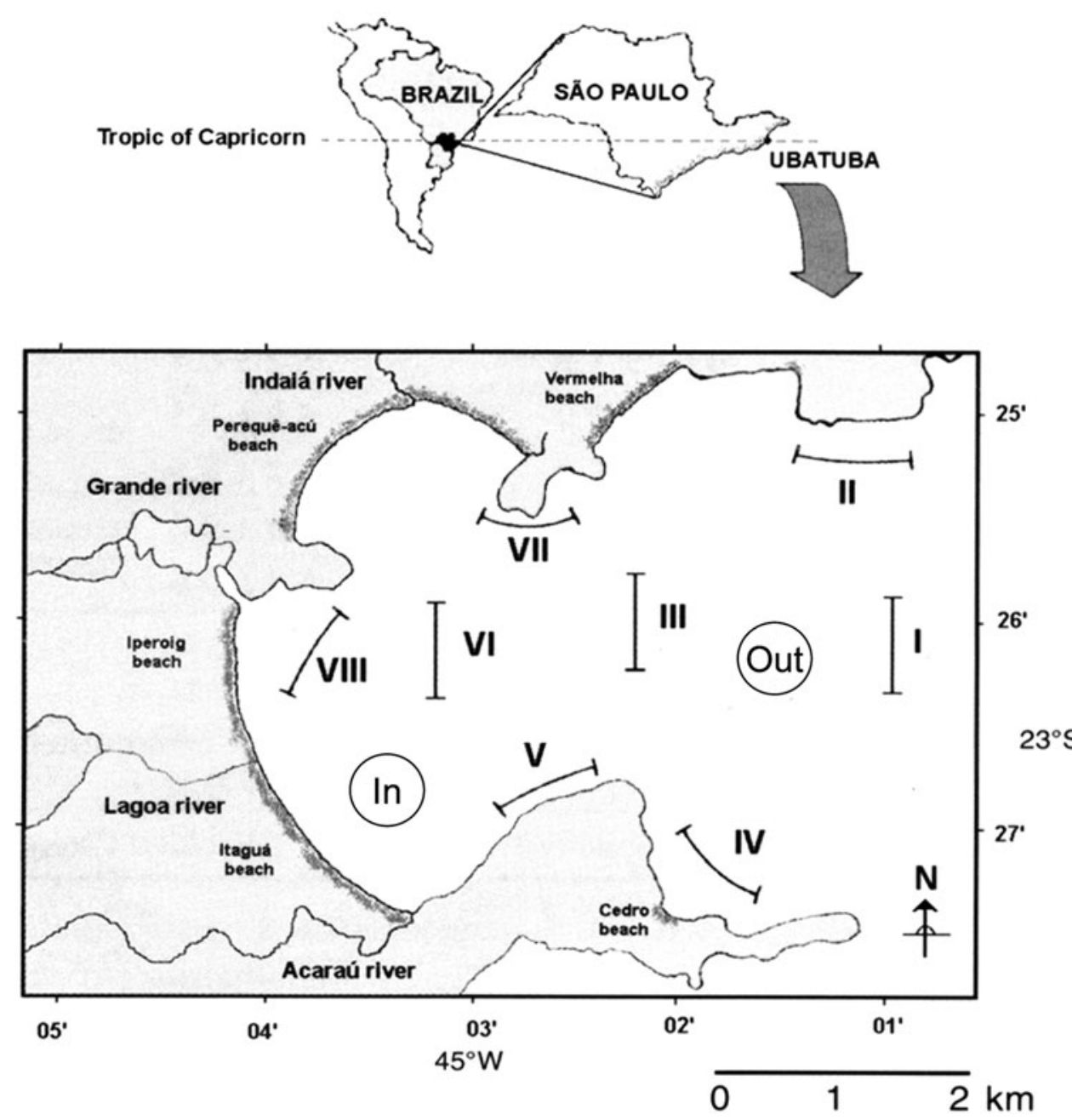

Fig. 1. Ubatuba Bay, indicating the sampling transects (In, inner bay; Out, outer bay). 
( $0.2 \mathrm{~mol} / \mathrm{l})$ and stirred for 5 minutes. This procedure resulted in the release of silt and clay particles. Next, sub-samples were rinsed in a $0.063 \mathrm{~mm}$ sieve. Sediments were sieved again through a series of meshes with different diameters; $2 \mathrm{~mm}$ (for gravel retention); $2.0-1.0 \mathrm{~mm}$ (very coarse sand); $1.0-0.5 \mathrm{~mm}$ (coarse sand); $0.5-0.25 \mathrm{~mm}$ (medium sand); $0.25-0.125 \mathrm{~mm}$ (fine sand) and $0.125-0.063 \mathrm{~mm}$ (very fine sand). Smaller particles were classified as silt-clay. Cumulative particle-size curves were plotted using the Phi scale. Phi values were calculated using the formula $\varphi=-\log _{2} d$, where $d=$ grain diameter $(\mathrm{mm})$. The mean diameter (MD) of sediment samples was determined from these Phi values (corresponding to the 16th, 50th and 84th percentiles) using the formula $\mathrm{MD}=\left(\varphi_{16}+\varphi_{50}+\varphi_{84}\right) / 3$ (Suguio, 1973). Sediment texture was examined visually by plotting triangular diagrams using the three granulometric classes with the highest proportions (Magliocca \& Kutner, 1965). Granulometric Class A corresponds to sediments in which intermediate sand (IS), coarse sand (CS), very coarse sand (VCS) and gravel (G $>0.25 \mathrm{~mm}$ ) account for $>70 \%$ of total weight. In Class B, fine sand (FS) and very fine sand (VFS) make up $>70 \%$ of total weight of sediment samples $(0.25-0.0625 \mathrm{~mm})$. More than $70 \%$ of sediments in Class $\mathrm{C}$ are silt and clay $(S+C)$.

Finally, organic-matter content of sediment samples was estimated as the difference between initial and final ash-free dry weights of three sub-samples (10 g each) incinerated in porcelain crucibles at $500^{\circ} \mathrm{C}$ for 3 hours.

\section{Analysis of shrimp abundance}

Shrimp abundance at each sampling site is represented as catch per unit effort (CPUE). First, we conducted an initial comparison among transects using a two-way ANOVA with season and transect as independent variables and CPUE as dependent variable. Homoscedasticity and normality of the data set were evaluated and found satisfactory after logarithmic transformation of the data.

This initial analysis demonstrated that the distribution of the shrimp in the bay was highly patchy (see Results). Also, a large proportion of our data set contained zero values and more than $95 \%$ of the shrimps were captured at a single transect. Thus, we decided to conduct a second analysis to examine the effect of the studied variables on the abundance of shrimp during the year only using the data from this single transect (Transect II) from which most shrimps were collected. For this purpose we conducted a multiple regression analysis.

The regression analysis was conducted within a model selection framework. First, we generated different models containing different sets of explanatory variables (salinity, temperature, sediment characteristics and dissolved oxygen concentrations). We started with a full model containing all the variables and proceeded to eliminate one by one those variables that contributed the least to the model (those with the greatest $P$ values). This process was repeated up to the point in which all variables contained in the model had a $P<$ o.2. Next, we determined the 'best' model (the model that minimizes the loss of information, and thus, best approximates reality given our data set) using an information theoretical approach. Selection among different models was based in Akaike's information criterion (Akaike, 1973). AIC was calculated for each of the different models using the residual sum of squares obtained with Proc nlin in the software SAS version 9.1 (SAS Institute, 2004). Because sample size was small (the ratio of observations to model parameters was less than 40), the corrected AIC ( $\mathrm{AIC}_{\mathrm{c}}$ ) was used to select between models (Burnham \& Anderson, 2002). The model with the lowest $\mathrm{AIC}_{\mathrm{c}}$ value (the best-fitting and most parsimonious model) was selected as the best model. Lastly, we determined the effect of each variable contained in this best model on the abundance of the shrimp.

\section{RESULTS}

Ubatuba Bay was characterized by moderate changes in temperature and salinity throughout the year. Average temperature was greater during summer and autumn than during spring and winter (Figure 2). In turn, average salinity was rather constant through the year other than during spring where it decreased all along the bay (Figure 2). Sediment grain composition remained almost the same throughout the year at each sampling station. Transects located in the middle of the bay (Transects III, VI and VIII) had higher concentrations of mud (Figure 3) and moderate amounts of organic matter (Figure 3). Transects located at the southernmost part of the bay (IV and V) had the smallest Phi values; sediments were mostly composed of medium sand and average organic matter was the highest within the bay (Figure 3). Transects located in the northern rim of the bay (II and VII) and the most exposed Transect I located in the middle of the outer bay were characterized by the presence of fine/very find sand. Taking into consideration sediment characteristics, the northernmost part of the bay was relatively protected compared to its southernmost part.

A total of 16,219 shrimps of N. schmitti were captured from a total of 288 trawls conducted throughout the sampling period. Although shrimps were caught from most transects within the bay, most of them ( $95 \%$ of the total catch) were retrieved from Transect II, located at the northernmost part of the outer bay (percentage of capture per transect: $\mathrm{I}=1 \%$; $\mathrm{II}=95 \%$; III $=1 \%$; IV $<0.5 \% ; \mathrm{V}<0.5 \% ; \mathrm{VI}=1 \% ; \mathrm{VII}=$ $2 \%$; VIII $<0.5 \%$ ). Thus, the spatial distribution of N. schmitti was extremely patchy.

Shrimp abundance varied among transects and seasons of the year (two way ANOVA after $\log +1$ transformation: transect; $\mathrm{F}=35.75, \mathrm{df}=7,64, P<0.001$ : season; $\mathrm{F}=7.51$, $\mathrm{df}=3,64, P<0.001$ ) (Figure 4 ). Shrimps were most abundant during winter, when the lowest average water temperature $\left(20.9 \pm 1.9^{\circ} \mathrm{C}\right)$ was registered for most of the bay. In contrast, the lowest abundance of $N$. schmitti occurred during the summer characterized by the highest temperatures during the sampling period. The interaction between season and transect in the ANOVA was also significant, explained by the patchy distribution of this shrimp and fluctuations in abundance, high at some transects but moderate or low at others $(\mathrm{F}=6.03, \mathrm{df}=21,64, P=0.0108)$ (Figure 4 ).

The multiple regression analysis only considered data from Transect II from which most shrimp (95\%) were collected. Using the $\mathrm{AIC}_{\mathrm{c}}$, the best model explaining variations in abundance of N. schmitti in this transect throughout the year was that containing the variables temperature, dissolved oxygen and organic matter (Table 1). In this best model, temperature negatively affected shrimp abundance $(P=0.0374)$. No effect of dissolved oxygen was detected and organic matter was marginally non-significant (Table 1). In general, at smaller 


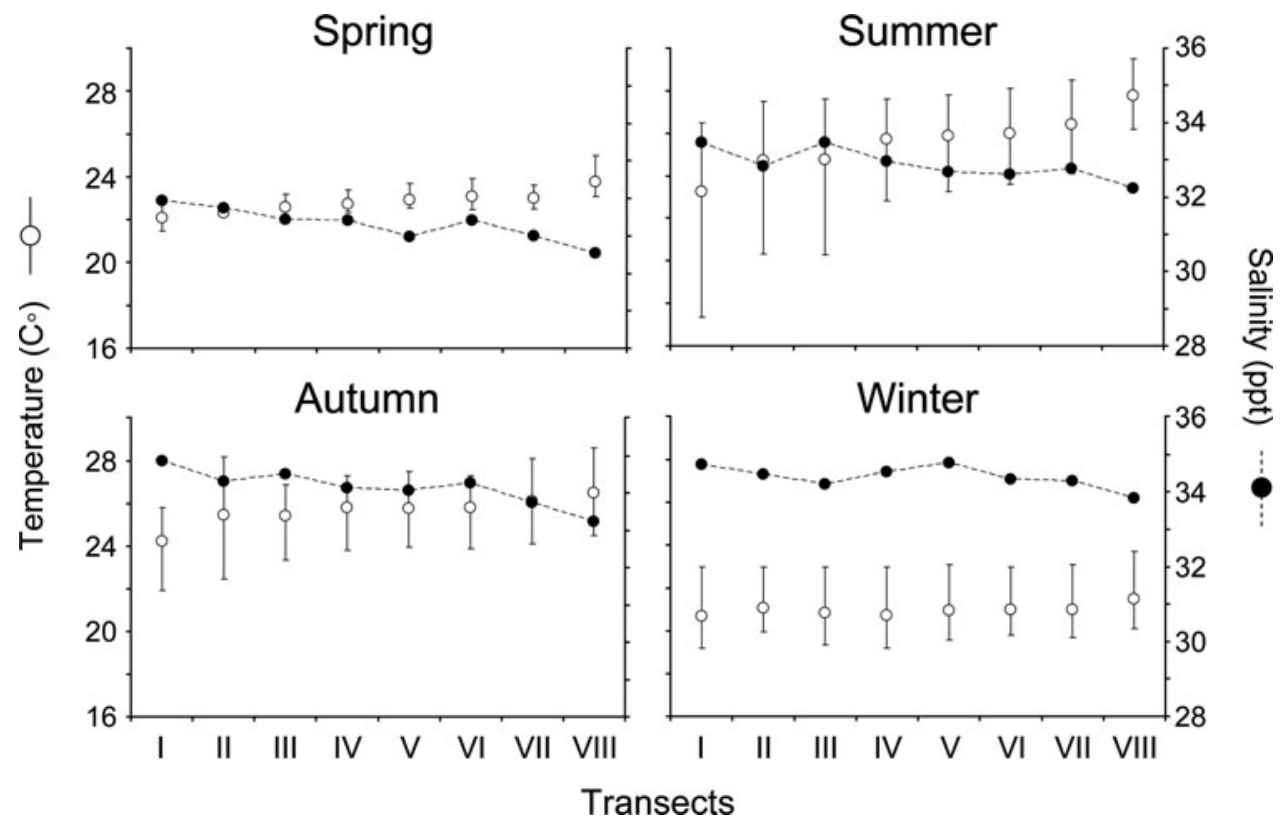

Fig. 2. Salinity and temperature variation (mean \pm standard deviation) at Ubatuba Bay during the sampling period.

temporal scales (months), temperature is the only parameter in our model that explains variation in abundance of N. schmitti at Ubatuba Bay.

\section{DISCUSSION}

In Ubatuba Bay, N. schmitti was restricted almost entirely to a small portion of the bay; over $95 \%$ out of 16,219 shrimp were
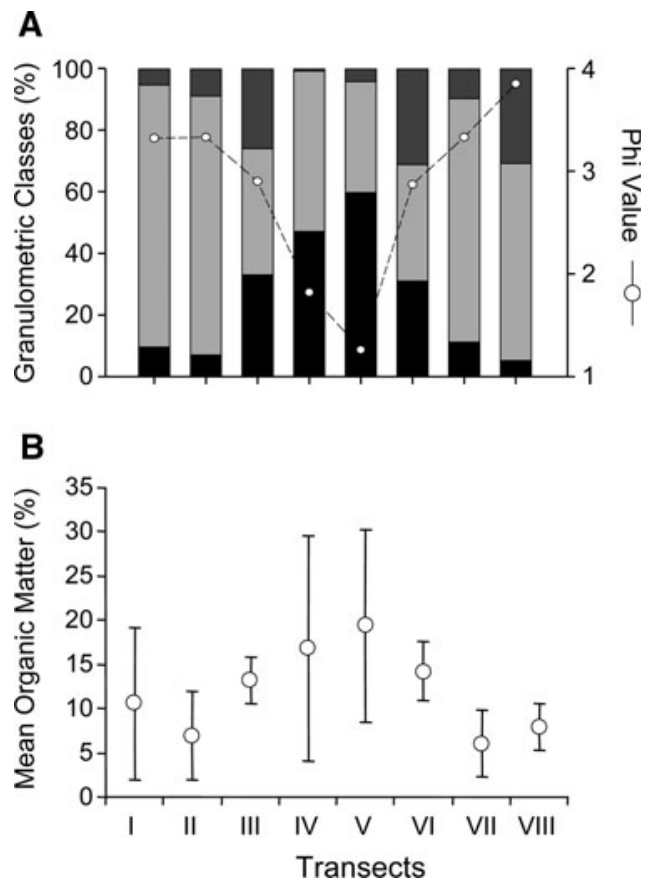

Fig. 3. Granulometry and organic content of the sediments at Ubatuba Bay. (A) Percentage of grain classes and Phi values. Grain classes (\%) are: light grey $=$ class $\mathrm{A}$, dark gray $=$ class $\mathrm{B}$, black = class $\mathrm{C}$; $(\mathrm{B})$ organic content (see Materials and Methods for details). collected from the northernmost end of the outer bay. Most interestingly, Fransozo et al. (2005) reported a similar distribution pattern for the spiny shrimp Exhippolysmata oplophoroides (Holthuis, 1948). More than 92\% of the catch during one complete year of sampling was collected from the same locality in which N. schmitti was most abundant. A priori, we expected this site to be different from the rest of the stations within the bay in terms of temperature, salinity, dissolved oxygen, sediment grain composition and/or organic matter. Nevertheless, we found only minor differences across transects with respect to the parameters above. Interestingly, the northernmost end of Ubatuba Bay (e.g. Transect II) is reported to support large amounts of plant debris floating immediately on top of the sediment (Mahiques et al., 1998; Mantelatto \& Fransozo, 1999). During our samplings, we indeed observed such debris, not exclusively but most commonly at Transect II. Unfortunately, no estimation of debris biomass was recorded, but we believe that this land derived material might be the key to explain the patchy distribution of this and other caridean shrimp within the bay.

Plant debris might be exported from land through the small freshwater streams or larger rivers merging into the bay. This debris might accumulate in Transect II given the pattern of currents within the bay (Ab'saber, 1955; Mahiques, 1995). We do not know if the presence of this detritus results in direct or indirect benefits to N. schmitti. To the best of our knowledge, the diet of marine shrimp, including other species from the same genus, does not rely on land derived material (the congener $N$. hastatus (Aurivillius, 1898 ) is primarily a carnivore of smaller marine organisms-Marioghae, 1989). Thus, small pieces of wood, sticks and leaves composing this debris might not necessarily represent a localized food source for shrimps, putatively explaining the extreme patchiness of $N$. schmitti within the bay. On the other hand, this large biomass of land derived bio-detritus might provide protection against predators as it most probably creates environmental heterogeneity in this structurally 


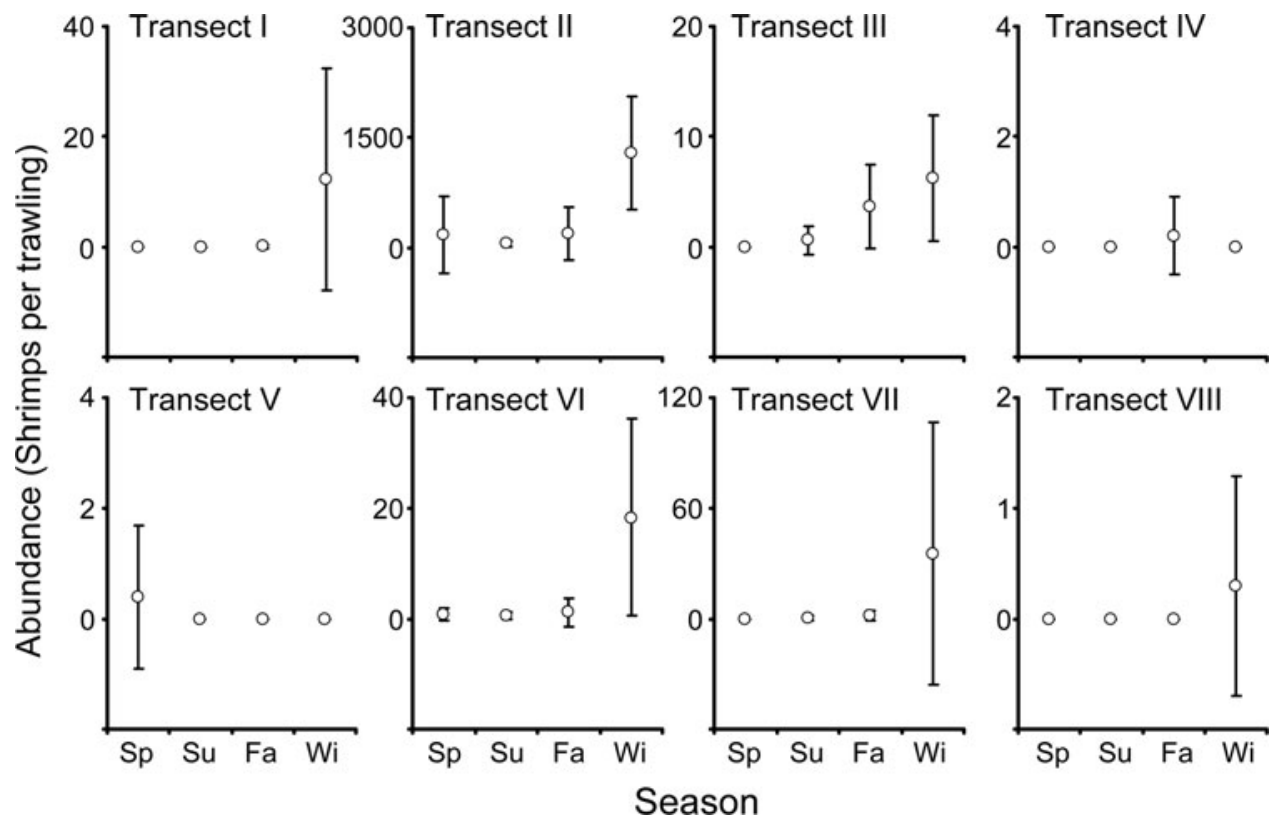

Fig. 4. Seasonal catch of Nematopalaemon schmitti in each transect during September, 1995 to August, 1996.

simple soft bottom habitat. The importance of environmental heterogeneity as a driver of species richness and biomass is well established in several marine habitats (Lenihan \& Micheli, 2001). Also, several shrimp species are known to use and actively select heterogeneous microhabitats (e.g. algae) as shelter against predators (Fransozo et al., 2002). Overall, the presence of land derived material at Ubatuba Bay represents an opportunity to explore sea-land connections and the relevance of land derived material in controlling the distribution and abundance of marine invertebrates in relatively deep coastal areas.

Our analysis demonstrated the importance of temperature in affecting the abundance of the studied shrimp. Nematopalaemon schmitti was most abundant during the winter $(75 \%$ of the specimens were collected during this season), when temperature reached low average values $\left(20.9^{\circ} \mathrm{C}\right)$ and was relatively homogeneous within the bay. This sharp increase in shrimp abundance might be the consequence of recruitment during this time of the year, as shown for other sympatric shrimp (Farfantepenaeus spp.-Costa \& Fransozo 1999; X. kroyeri-Castro et al., 2005; E. oplophoroides-Fransozo et al., 2005). Alternatively, this sudden increase in abundance might be explained by shrimp migrations from deeper waters. A few studies have revealed shrimp migratory behaviours from deeper to shallow areas during specific times of a year (e.g. Palaemon adspersus

Table 1. The best multiple regression analysis model selected by the Akaike information criterion explaining changes in the abundance of Nematopalaemon schmitti at the northernmost end (Transect II) of Ubatuba Bay.

\begin{tabular}{lllll}
\hline Parameter & Estimate & Error & Statistic & \multicolumn{1}{l}{$\boldsymbol{P}$} \\
\hline Constant & 5081.83 & 1574.14 & 3.22833 & 0.0121 \\
Organic matter & -96.7633 & 45.0243 & -2.14913 & 0.0639 \\
Oxygen & -261.645 & 167.037 & -1.56638 & 0.1559 \\
Temperature & -118.78 & 47.6681 & -2.4918 & 0.0374 \\
\hline
\end{tabular}

Rathke, 1837, P. elegans Rathke, 1837 and Crangon crangon (Linnaeus, 1758)-Bilgin et al., 2008 and references therein). Studies on the population dynamics of $N$. schmitti will be most useful to understand fluctuations in its abundance throughout the year at the study site.

Unexpectedly, our data suggest that sediment characteristics and organic matter do not affect the abundance of $N$. schmitti within the bay. Sediment characteristics are known to control the distribution and abundance of several shrimp species (Wenner et al., 1983; Abelló et al., 1988). Similarly, organic matter deposited between sediment particles is a recognized food resource for benthic organisms (epifaunal, infaunal and interstitial), including detritivorous/ carnivorous shrimp (Bertini \& Fransozo, 1999). Thus, we were expecting an effect of organic matter in the abundance of N. schmitti given its relevance for other species. On the other hand, observations of living N. schmitti shrimp in the laboratory demonstrated that individuals are constantly swimming $\sim 30-50 \mathrm{~cm}$ above the bottom of aquaria. If these laboratory observations do represent the behaviour of shrimp in the field, then the absence of direct contact with the substrate might explain why sediment characteristics were not relevant in affecting the distribution of this shrimp.

Overall, this study improved our understanding of the conditions affecting the distribution of $N$. schmitti at relatively large spatial and small temporal scales. We believe that future studies should focus in testing the influence of land derived organic material in the distribution of $N$. schmitti and other sympatric shrimp (e.g. E. oplophoroides) in the region. Caridean shrimps from the south-west Atlantic might be used as models to explore land-sea connectivity in subtropical areas. Also, we believe that the study of additional biological parameters (e.g. competition, predation and larval supply), day/night variations of shrimp abundance, and shrimp behaviour would contribute substantially to our understanding of shrimp distribution in soft bottom communities. 


\section{ACKNDWLEDGEMENTS}

Thanks to FAPESP for providing us with infrastructure during our field and laboratory work. Many thanks to Drs Christopher Tudge (American University, Washington) and Janet W. Reid (Virginia Museum of Natural History, Virginia) for their valuable comments on earlier versions of this manuscript. We appreciate the invaluable help of the NEBECC crew during field and laboratory activities. J.A.B. thanks the support from a STRI Marine Postdoctoral Fellowship and a SMSFP Postdoctoral Fellowship. Sampling was conducted according to the São Paulo State and Brazilian federal laws. We appreciate the helpful comments by two anonymous referees. This is contribution number 783 from the Smithsonian Marine Station at Fort Pierce.

\section{REFERENCES}

Ab'Saber A.N. (1955) Contribuição à geomorfologia do litoral paulista. Revista Brasileira de Geografia 1, 1-37.

Abelló P., Valladares F.J. and Castellón A. (1988) Analysis of the structure of decapod crustacean assemblages off the Catalan coast (North-West Mediterranean). Marine Biology 98, 39-49.

Akaike H. (1973) Information theory and an extension of the maximum likelihood principle. In Petrov BN and Czaki F. (eds) 2nd International Symposium on Information Theory. Budapest: Akademiai Kiado, pp. $267-281$.

Bertini G. and Fransozo A. (1999) Spatial and seasonal distribution of Petrochirus diogenes (Anomura, Diogenidae) in the Ubatuba Bay, São Paulo, Brazil. Iheringia 86, 145-150.

Bilgin S., Ozen O. and Ates A.S. (2008) Spatial and temporal variation of Palaemon adspersus, Palaemon elegans, and Crangon crangon (Decapoda: Caridea) in the southern Black Sea. Estuarine, Coastal and Shelf Science 79, 671-678.

Buchanan B.A. and Stoner A.W. (1988) Distributional patterns of blue crabs (Callinectes spp.) in a tropical estuarine lagoon. Estuaries 11, 231-239.

Burnham K.P. and Anderson D.R. (2002) Model selection and multimodel inference: a practical information-theoretic approach. New York: Springer-Verlag.

Burone L. and Pires-Vanin A.M.S. (2006) Foraminiferal assemblages in Ubatuba Bay, southeastern Brazilian coast. Scientia Marina 70, 203-217.

Caillaux L.M. and Stotz W.B. (2003) Distribution and abundance of Rhynchocinetes typus (Crustacea: Decapoda), in different benthic community structures in northern Chile. Journal of the Marine Biological Association of the United Kingdom 83, 143-150.

Castilho A.L., Furlan M., Costa R.C. and Fransozo V. (2008a) Abundance and temporal-spatial distribution of the rock shrimp Sicyonia dorsalis Kingsley, 1878 (Decapoda, Penaeoidea) from the northern coast of São Paulo state, Brazil. Senckenbergiana Maritima $38,75-83$.

Castilho A.L., Pie M.R., Fransozo A., Pinheiro A.P. and Costa R.C. (2008b) The relationship between environmental variation and species abundance in shrimp community (Crustacea: Decapoda: Penaeoidea) in south-eastern Brazil. Journal of the Marine Biological Association of the United Kingdom 88, 119-123.

Castro R.H., Costa R.C., Fransozo A. and Mantelatto F.L.M. (2005) Population structure of the seabob shrimp Xiphopenaeus kroyeri
(Heller, 1862) (Crustacea: Penaeoidea) in the littoral of São Paulo, Brazil. Scientia Marina 69, 105-112.

Chacur M.M. and Negreiros-Fransozo M.L. (2001) Spatial and seasonal distributions of Callinectes danae (Decapoda, Portunidae) in Ubatuba Bay, São Paulo, Brazil. Journal of Crustacean Biology 21, 414-425.

Costa R.C. and Fransozo A. (1999) A nursery ground for two tropical pink-shrimp Farfantepenaeus species: Ubatuba Bay, northern coast of São Paulo, Brazil. Nauplius 7, 73-81.

Costa R.C., Fransozo A. and Pinheiro A.P. (2004) Ecological distribution of the shrimp Pleoticus muelleri (Bate, 1888) (Decapoda: Penaeoidea) in southeastern Brazil. Hydrobiologia 529, 195-203.

Costa R.C., Fransozo A. and Negreiros-Fransozo M.L. (2005a) Ecology of the rock shrimp Sicyonia dorsalis Kingsley, 1878 (Crustacea: Sicyoniidae) in a subtropical region of Brazil. Gulf and Caribbean Research 17, 49-56.

Costa R.C., Fransozo A., Castilho A.L. and Freire F.A.M. (2005b) Annual, seasonal and spatial variation of abundance of the shrimp Artemesia longinaris (Decapoda: Penaeoidea) in south-eastern Brazil. Journal of the Marine Biological Association of the United Kingdom $85,107-112$

Costa R.C., Fransozo A., Freire F.A.M. and Castilho A.L. (2007) Abundance and ecological distribution of the 'sete-barbas' shrimp Xiphopenaeus kroyeri (Heller, 1862) (Decapoda: Penaeoidea) in three bays of the Ubatuba region, southeastern Brazil. Gulf and Caribbean Research 19, 33-41.

Fransozo A., Costa R.C., Mantelatto F.L.M., Pinheiro M.A.A. and Santos S. (2002) Composition and abundance of shrimp species (Penaeidea and Caridea) in Fortaleza Bay, Ubatuba, São Paulo, Brazil. In Briones E.E. and F. Alvarez (eds) Modern approaches to the study of Crustacea. Dordrecht: Kluwer Academic Publishers, pp. $117-123$.

Fransozo A., Costa R.C., Castilho A.L. and Mantelatto F.L. (2004) Ecological distributions of the shrimp 'camarão serrinha' Artemesia longinaris (Decapoda, Penaeidae) in Fortaleza Bay, Ubatuba, Brazil, in relation to abiotic factors. Revista de Investigación y Desarrollo Pesquero 16, 43-50.

Fransozo V., Costa R.C., Bertini G., and Cobo V.J. (2005) Population biology of spine shrimp Exhippolysmata oplophoroides (Holthuis) (Caridea, Hippolytidae) in a subtropical region, São Paulo, Brazil. Revista Brasileira de Zoologia 22, 1078-1084.

Golterman H.L. and Clymo R.S. (1969) Methods for chemical analysis of freshwaters. Oxford: Blackwell Scientific Publications.

Hakanson L. and Jansson M. (1983) Principles of lake sedimentology. Berlin: Springer-Verlag.

Henderson P.A., Seaby R.M. and Somes J.R. (2006) A 25-year study of climatic and density-dependent population regulation of common shrimp Crangon crangon (Crustacea: Caridea) in the Bristol Channel. Journal of the Marine Biological Association of the United Kingdom 86, 287-298.

Holthuis L.B. (1980) Shrimps and prawns of the world: an annotated catalogue of species of interest to fisheries. FAO Species Catalogue. FAO Fisheries Synopsis 1, 1-270.

Jensen G.C. and Armstrong D.A. (1991) Intertidal zonation among congeners: factors regulating distribution of porcelain crabs Petrolisthes ssp. (Anomura: Porcellanidae). Marine Ecology Progress Series 73, $47-60$

Lenihan H.S. and Micheli F. (2001) Soft-sediment communities. In Bertness MD, Gaines SD and Hay ME (eds) Marine community ecology. Sunderland, MA: Sinauer Associates. 
Magliocca A. and Kutner A.S. (1965) Sedimentos de fundo da Enseada do Flamengo, Ubatuba, SP. Contribuições do Instituto Oceanográfico $198,1-15$.

Mahiques M.M. (1995) Dinâmica sedimentar atual nas Enseadas da região de Ubatuba, Estado de São Paulo. Boletim do Instituto Oceanográfico $43,111-122$.

Mahiques M.M., Tessler M.G. and Furtado V.V. (1998) Characterization of energy gradient in enclosed bays of Ubatuba region, South-eastern Brazil. Estuarine, Coastal and Shelf Science 47, 431-446.

Mantelatto F.L.M. and Fransozo A. (1999) Characterization of the physical and chemical parameters of Ubatuba Bay, northern coast of São Paulo State, Brazil. Revista Brasileira de Biologia 59, 23-31.

Marioghae I.E. (1989) Trophic relationships of the white estuarine prawn Nematopalaemon hastatus (Aurivillius, 1898) (Decapoda, Palaemonidae). Revue d'Hydrobiolgie Tropicale 22, 289-294.

Nakagaki J.M. and Negreiros-Fransozo M.L. (1998) Population biology of Xiphopenaeus kroyeri (Heller 1862) (Decapoda: Penaeidae) from Ubatuba Bay, São Paulo Brazil. Journal of Shellfish Research 17 , 931-935.

Nucci P.R., Turra A. and Morgado E.H. (2001) Diversity and distribution of crustaceans from 13 sheltered sandy beaches along São Sebastião Channel, south-eastern Brazil. Journal of the Marine Biological Association of the United Kingdom 81, 475-484.

Pallas A., Garcia-Calvo B., Corgos A., Bernardez C. and Freire J. (2006) Distribution and habitat use patterns of benthic decapod crustaceans in shallow waters: a comparative approach. Marine Ecology Progress Series $324,173-184$

Pinheiro M.A.A., Fransozo A. and Negreiros-Fransozo M.L. (1994) Distribution patterns of Arenaeus cribrarius (Lamarck, 1818)
(Crustacea, Portunidae) in Fortaleza Bay, Ubatuba (SP), Brazil. Revista Brasileira de Zoologia 56, 705-716.

SAS Institute (2004) SAS/STAT software. Version 9.1. Cary, NC: SAS Institute.

Suguio K. (1973) Introdução à sedimentologia. São Paulo: Universidade de São Paulo.

Takeda S., Poovachiranon S. and Murai M. (2004) Adaptions for feeding on rock surfaces and sandy sediment by the fiddler crabs (Brachyura: Ocypodidae) Uca tetragonon (Herbst, 1790) and Uca vocans (Linnaeus, 1758). Hydrobiologia 528, 87-97.

Tucker M. (1988) Techniques in sedimentology. Oxford: Blackwell Scientific Publications.

Viegas I., Martinho F., Neto J. and Pardal N. (2007) Population dynamics, distribution and secondary production of the brown shrimp Crangon crangon (L.) in a southern European estuary: latitudinal variations. Scientia Marina 71, 451-460.

and

Wenner E.L., Knott D.M., Van Dolah R.F. and Burrell V.G. Jr. (1983) Invertebrate communities associated with hard bottom habitats in the South Atlantic Bight. Estuarine, Coastal and Shelf Science 17, 143-158.

\section{Correspondence should be addressed to:}

J.A. Baeza

Smithsonian Marine Station at Fort Pierce

701 Seaway Drive

Fort Pierce

Florida 34949, USA

email: baezaa@si.edu 